\title{
Combination of Chemo- and Biocatalysis: Conversion of Biomethane to Methanol and Formic Acid
}

\author{
Benny Kunkel ${ }^{1}$, Dominik Seeburg ${ }^{1}$, Tim Peppel ${ }^{1}$ (), Matthias Stier ${ }^{2}$ and Sebastian Wohlrab ${ }^{1, *}$ \\ 1 Leibniz Institute for Catalysis at the University of Rostock, Albert-Einstein-Str. 29a, \\ D-18059 Rostock, Germany \\ 2 Fraunhofer Institute for Interfacial Engineering and Biotechnology IGB, Nobelstraße 12, \\ D-70569 Stuttgart, Germany \\ * Correspondence: sebastian.wohlrab@catalysis.de; Tel.: +49-381-1281-328
}

Received: 14 June 2019; Accepted: 9 July 2019; Published: 12 July 2019

check for updates

\begin{abstract}
In the present day, methanol is mainly produced from methane via reforming processes, but research focuses on alternative production routes. Herein, we present a chemo-/biocatalytic oxidation cascade as a novel process to currently available methods. Starting from synthetic biogas, in the first step methane was oxidized to formaldehyde over a mesoporous $\mathrm{VO}_{\mathrm{x}} / \mathrm{SBA}-15$ catalyst. In the second step, the produced formaldehyde was disproportionated enzymatically towards methanol and formic acid in equimolar ratio by formaldehyde dismutase (FDM) obtained from Pseudomonas putida. Two processing routes were demonstrated: (a) batch wise operation using free formaldehyde dismutase after accumulating formaldehyde from the first step and (b) continuous operation with immobilized enzymes. Remarkably, the chemo-/biocatalytic oxidation cascades generate methanol in much higher productivity compared to methane monooxygenase (MMO) which, however, directly converts methane. Moreover, production steps for the generation of formic acid were reduced from four to two stages.
\end{abstract}

Keywords: selective oxidation; molecular $\mathrm{VO}_{\mathrm{x}}$ catalysts; formaldehyde dismutase; methanol; formic acid

\section{Introduction}

Nowadays, methane is mainly used as a source of energy [1] and its direct chemical utilization is restricted to the formation of (i) syngas [2,3] or (ii) hydrogen cyanide via the Andrussow or Degussa process [4] as well as (iii) for the production of methyl halides or carbon disulfide [5].

Oxygenates from methane, like methanol, formaldehyde or formic acid, are conventionally being produced via the syngas route because the direct production routes are rather limited. Homogeneous, heterogeneous and enzymatic direct catalytic conversions of methane primarily focus on the target molecule methanol. However, all of these approaches have certain restrictions like batchwise production, low productivity or selectivity owing to the nature of the applied chemistry [6].

The direct chemocatalytic synthesis of methanol from methane can be divided into homogeneous and heterogeneous methods. Among homogenous catalytic approaches the Periana system, [(bpym) $\mathrm{PtCl}_{2}$ ] (bpym: bipyrimidine), converts methane in oleum directly to methyl bisulfate as a methanol derivative with a productivity of $0.115 \mathrm{kgCH}_{3} \mathrm{OH} \cdot \mathrm{L}^{-1} \cdot \mathrm{h}^{-1}$ [7]. The major drawback of this reaction is the need for sulfur trioxide as transfer oxidant which makes it difficult to run the process in larger scale. Schüth and coworkers have found that $\mathrm{K}_{2}\left[\mathrm{PtCl}_{4}\right]$ exhibits a higher productivity $\left(0.48 \mathrm{kgCH}_{3} \mathrm{OH} \cdot \mathrm{L}^{-1} \cdot \mathrm{h}^{-1}\right)$, but $\mathrm{SO}_{3}$ concentration has to be even increased [8]. Milder oxidants, like oxygen or hydrogen peroxide have been investigated, too, but to the detriment of very low productivities [9-11]. In order to overcome limitations in productivity when using milder oxidants, the groups of Stahl and 
Strassner have recently shown that the concept of redox mediation could be a future way in activating alkanes [12,13].

Heterogeneous catalytic approaches work with immobilized Pt(II) species on N-rich covalent triazine frameworks (CTF), but this may also include oleum as solvent/oxidant [14]. Alternatively, milder oxidants have been used by the group of Hutchings which applied gold-palladium alloy nanoparticles for the oxidation with $\mathrm{H}_{2} \mathrm{O}_{2}$ [15] or aqueous Au-Pd colloids for the oxidation with $\mathrm{O}_{2}$ in the presence of $\mathrm{H}_{2} \mathrm{O}_{2}$ [16]. Obviously, the oxidation of methane with oxygen is still challenging. Several efforts have been made utilizing $\mathrm{Cu}$ sites incorporated in zeolites to activate methane and form methoxide species [17]. However, a subsequent hydrolyzing step with water is required in order to close the reaction cycle [18]. Recently and perhaps revolutionarily, Sushkevich et al. opened the possibility to transform methane to methanol by an anaerobic oxidation with water over copper-exchanged mordenite zeolite [19].

Biocatalysis shows that the activation of gas phase oxygen and its further reaction with methane is principally feasible. Enzymes classified as methane monooxygenases (MMO) [20-23], found in methanotrophic bacteria, do not only produce methanol selectively, but they also work under mild conditions of bacterial living. In soluble MMO (sMMO) di-iron clusters with bis- $\mu$-oxo diamond core structure are discussed as active sites [21] whereas in particulate $\mathrm{MMO}$ (pMMO) a tri-copper center catalyzes the reaction [24]. Synthetic approaches mimicking the active site of the latter have already been successfully demonstrated [25-27]. Although the direct conversion of methane to methanol is possible using such natural or biomimetic structures, conversion rates and turn over numbers, respectively, are rather low and chemocatalytic activation of methane remains preferred.

With regards to thermodynamic data [28] the fundamental problem of chemocatalytic approaches can be expressed as sensitivity of oxygenates against over-oxidation (see Equations (1)-(4)).

$$
\begin{array}{cc}
\mathrm{CH}_{4}+0.5 \mathrm{O}_{2} \rightarrow \mathrm{CH}_{3} \mathrm{OH} & \Delta \mathrm{G}^{\circ}=-27.7 \mathrm{kcal} \cdot \mathrm{mol}^{-1} \\
\mathrm{CH}_{4}+\mathrm{O}_{2} \rightarrow \mathrm{CH}_{2} \mathrm{O}+\mathrm{H}_{2} \mathrm{O} & \Delta \mathrm{G}^{\circ}=-69.1 \mathrm{kcal} \cdot \mathrm{mol}^{-1} \\
\mathrm{CH}_{4}+1.5 \mathrm{O}_{2} \rightarrow \mathrm{CO}+2 \mathrm{H}_{2} \mathrm{O} & \Delta \mathrm{G}^{\circ}=-134.0 \mathrm{kcal} \cdot \mathrm{mol}^{-1} \\
\mathrm{CH}_{4}+2 \mathrm{O}_{2} \rightarrow \mathrm{CO}_{2}+2 \mathrm{H}_{2} \mathrm{O} & \Delta \mathrm{G}^{\circ}=-195.5 \mathrm{kcal} \cdot \mathrm{mol}^{-1}
\end{array}
$$

However, the direct formation of formaldehyde from methane and oxygen has been known for years and satisfying selectivities can be achieved at low conversion $\left(\mathrm{X}_{\mathrm{CH}_{4}}<10 \%\right)$ [6]. At very low residence times the reaction can be controlled partially. During recent years, researchers focused their studies on methods to increase the productivity of this reaction [29-31] and found that a $\mathrm{CH}_{2} \mathrm{O}$ space-time yield above $5 \mathrm{~kg}_{\mathrm{CH}_{2} \mathrm{O}} \cdot \mathrm{kg}_{\mathrm{cat}}{ }^{-1} \cdot \mathrm{h}^{-1}$ is possible by using an optimized mesoporous silica supported $\mathrm{VO}_{\mathrm{x}}$ catalyst [32,33].

Ohkubo and Hirose transformed methane directly to methanol and formic acid via chlorine dioxide radicals under photoirradiation [34]. Moreover, self-disproportionation of formaldehyde to methanol and formic acid under hydrothermal or supercritical conditions occurs spontaneously [35,36]. However, both the products can be obtained under much milder conditions applied in an enzymatic conversion of formaldehyde. Formaldehyde dismutase (FDM; EC 1.2.99.4) is an enzyme which converts formaldehyde into methanol and formic acid [37,38]. By a so-called flip-flop mechanism, formaldehyde is disproportionated to formic acid and methanol. Initially, hydrated formaldehyde is oxidized to formic acid. Thereafter the reduction equivalents are transferred to the enzyme bound cofactor $\mathrm{NAD}^{+}$ which is regenerated by the reduction of another formaldehyde molecule to methanol. As described by Rodewyk [39], the enzyme is independent of further cofactors and very robust. The associated and self-regenerating cofactor makes the FDM interesting to use as a technical enzyme because neither an additional cofactor has to be added nor an alternative regeneration path has to be developed. Most importantly, the specific activity of FDM can be up to 6000 times higher compared to MMO $\left(138,000 \pm 16,000 \mathrm{nmol}_{\mathrm{CH}_{3} \mathrm{OH}} \cdot \mathrm{mg}^{-1} \cdot \mathrm{min}^{-1}\right.$ vs. $22.9 \pm 6.1 \mathrm{nmol}_{\mathrm{CH}_{3} \mathrm{OH}} \cdot \mathrm{mg}^{-1} \cdot \mathrm{min}^{-1}$ over FDM [38] and 
pMMO [24], respectively). This led us to the idea to combine highly productive chemocatalytic methane oxidation with fast biocatalytic conversion of the formaldehyde intermediate to generate methanol and formic acid in equimolar amounts.

Scheme 1 compares the different routes for methanol production: (i) in industrial scale including formic acid synthesis, (ii) via direct oxidation routes and (iii) the here presented chemo-/biocatalytic oxidation cascade.

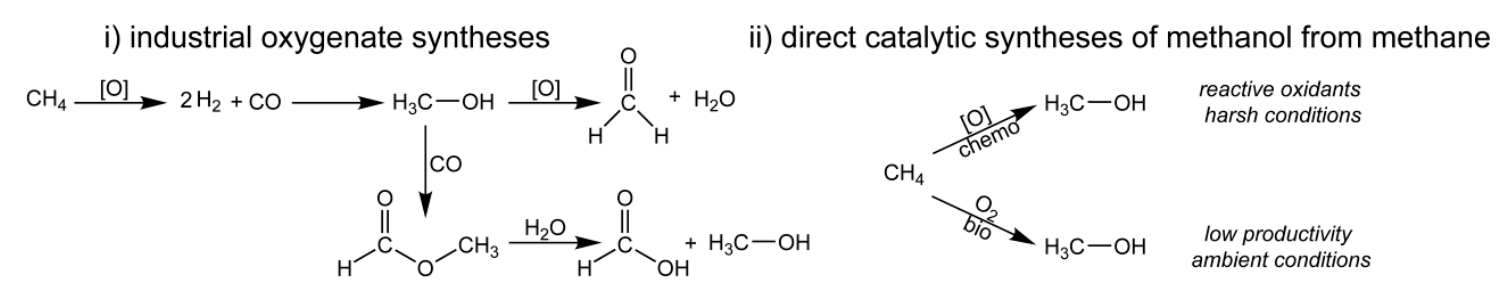

iii) combination of chemo- and biocatalysis: methane to oxygenates

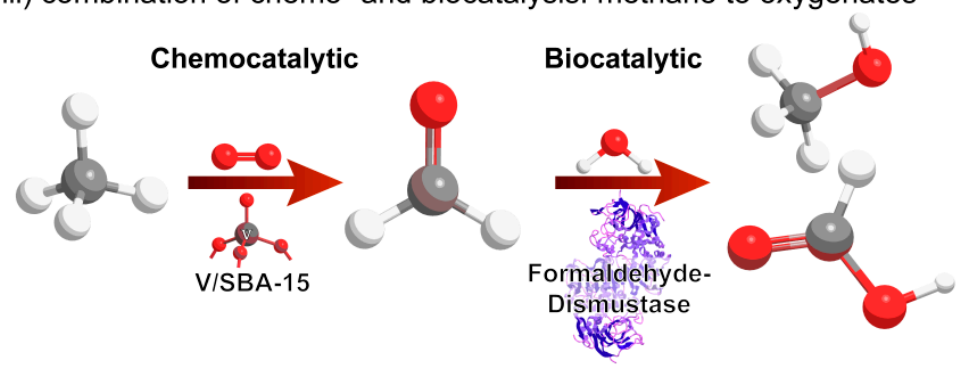

Scheme 1. Currently available conversion routes to produce methanol from methane (i,ii) and the herein presented chemo/-biocatalytic oxidation cascade (iii) (The formaldehyde dismutase, FDM, structure was generated from Hasegawa et al. [40]).

The latter, our approach, uses molecular oxygen in the chemocatalytic methane activation step followed by a relatively fast (selective) biocatalytic methanol production, additionally yielding formic acid in equimolar amounts. Moreover, methane from mimicked biogas $\left(\mathrm{CH}_{4}: \mathrm{CO}_{2}=1: 1\right)$ was utilized in this work to further explore this renewable feedstock, which is produced at a scale of $\mathrm{Gm}^{3} \cdot \mathrm{a}^{-1}$ [41]. The following results should be also set into context of presently discussed methanol production routes from biogas which follow the conventional syngas strategy [42] or might use the hydrogenation of carbon dioxide [43-46]. Clearly, the following results represent insights of a new, alternative route to already existing methods from biomethane to methanol.

\section{Materials and Methods}

\subsection{Chemocatalysis}

Plain SBA-15 was synthesized as described by Iglesias et al. [47]. In brief, $8 \mathrm{~g}$ Pluronic P123 (Aldrich, St. Louis, MO, USA, $1.4 \mathrm{mmol}$ ) was diluted in $240 \mathrm{~g}$ of $2 \mathrm{M} \mathrm{HCl}$ (Fisher Scientific, Pittsburgh, PA, USA) at $40^{\circ} \mathrm{C}$. Afterwards $17.35 \mathrm{~g}$ tetraethyl orthosilicate (Aldrich, $98 \%, 83.3 \mathrm{mmol}$ ) was added dropwise to the solution, which was further stirred for $24 \mathrm{~h}$ at $40{ }^{\circ} \mathrm{C}$. Subsequently the resulting suspension was treated hydrothermally in an autoclave with a PTFE inlet at $100{ }^{\circ} \mathrm{C}$. After $24 \mathrm{~h}$ the white solid was isolated and washed with deionized water until the filtrate was free of $\mathrm{Cl}^{-}$. The solid residue was dried overnight at $70{ }^{\circ} \mathrm{C}$ and calcined for $16 \mathrm{~h}$ at $625^{\circ} \mathrm{C}$ (heating rate $1 \mathrm{~K} \cdot \mathrm{min}^{-1}$ ) in air.

The functionalization of SBA- 15 with $\mathrm{VO}_{\mathrm{x}}$ species was prepared as described by Baltes et al. [48]. $2.7 \mathrm{~g} \mathrm{VO}(\mathrm{acac})_{2}$ (Strem Chemicals, 98\%, Newburyport, MA, USA, $10.2 \mathrm{mmol}$ ) was dissolved in $450 \mathrm{~mL}$ of dry toluene in argon atmosphere. To this solution $4.5 \mathrm{~g}$ SBA- 15 which was dried overnight at $120^{\circ} \mathrm{C}$ was added and stirred for $5 \mathrm{~h}$ at room temperature. Afterwards, the solid was isolated and washed four times with toluene, followed by drying at $70{ }^{\circ} \mathrm{C}$ overnight and calcination at $625^{\circ} \mathrm{C}$ for $16 \mathrm{~h}$ in air 
(heating rate $1 \mathrm{~K} \cdot \mathrm{min}^{-1}$ ) yielding $4.4 \mathrm{~g}$ of a bright yellow solid. The resulting catalyst is denoted as V/SBA-15.

Catalytic oxidation of methane was carried out in a horizontal fixed bed plug flow reactor consisting of a quartz tube with an inner diameter of $8 \mathrm{~mm}$. Experiments were performed with $25 \mathrm{mg}$ of the catalyst placed in the center of the quartz tube, fixed by quartz wool. Behind the catalyst bed the inner diameter of the reactor decreases to $4 \mathrm{~mm}$. The oven temperature was controlled by a thermocouple in the middle of the catalyst bed. The catalytic performance was measured in a temperature range of $575-650{ }^{\circ} \mathrm{C}$ at atmospheric pressure for $30 \mathrm{~min}$ at each testing point after reaching steady state. The premixed reactant gas contained $\mathrm{CH}_{4}, \mathrm{CO}_{2}$ and $\mathrm{O}_{2}$ in a ratio of 9:9:1 (Air Liquide, N45, Düsseldorf, Germany) and the gas flow passing the reactor was controlled by a mass flow controller (MKS-Instruments, Andover, MA, US). The on-line gas analysis was carried out with a FT-IR spectrometer (Bruker Matrix-MG01, Ettlingen, Germany) and the Bruker software Opus GA which uses reference spectra of the single compounds and a nonlinear fitting algorithm.

Methane conversion $\left(\mathrm{X}_{\mathrm{CH}_{4}}\right)$, formaldehyde yield $\left(\mathrm{Y}_{\mathrm{CH}_{2} \mathrm{O}}\right)$, formaldehyde selectivity $\left(\mathrm{S}_{\mathrm{CH}_{2} \mathrm{O}}\right)$ and space-time yield $\left(\mathrm{STY}_{\mathrm{CH}_{2} \mathrm{O}}\right)$ were calculated according to Equations (5) to (8):

$$
\begin{gathered}
X_{\mathrm{CH}_{4}}=\frac{c_{\mathrm{CH}_{4}}^{f}-c_{\mathrm{CH}_{4}}^{p}}{c_{C \mathrm{CH}_{4}}^{f}} \cdot 100 \% \\
Y_{\mathrm{CH}_{2} \mathrm{O}}=\frac{c_{\mathrm{CH}_{2} \mathrm{O}}^{p}-c_{\mathrm{CH}_{2} \mathrm{O}}^{f}}{c_{\mathrm{CH}_{4}}^{f}} \cdot 100 \% \\
S_{\mathrm{CH}_{2} \mathrm{O}}=\frac{Y_{\mathrm{CH}_{2} \mathrm{O}}}{X_{\mathrm{CH}_{4}}} \cdot 100 \% \\
\operatorname{STY}_{\mathrm{CH}_{2} \mathrm{O}}=\frac{\dot{m}_{\mathrm{CH}_{2} \mathrm{O}}}{m_{c a t}}
\end{gathered}
$$

where $c_{i}^{f}$ and $c_{i}^{p}$ denote the concentration of component $i$ in the feed gas $f$ and product gas $p, \dot{m}_{\mathrm{CH}_{2} \mathrm{O}}$ the mass flow of formaldehyde and $m_{\text {cat }}$ the mass of the catalyst.

\subsection{Biocatalysis}

The heterologous expression of FDM from the Pseudomonas putida J3 strain by E. coli and its purification was described earlier [38]. Pseudomonas putida was isolated from sewage sludge at Fraunhofer-Institute for Interfacial Engineering and Biotechnology IGB Stuttgart and cultivated in a broth consisting of peptone $\left(10 \mathrm{~g} \cdot \mathrm{L}^{-1}\right)$, meat extract $\left(10 \mathrm{~g} \cdot \mathrm{L}^{-1}\right)$ and $\mathrm{NaCl}\left(5 \mathrm{~g} \cdot \mathrm{L}^{-1}\right)$ at a $\mathrm{pH}$ value between 7.0 and 7.2. After chemo-mechanical extraction of the genomic DNA the heterologous expression of the FDM J3 gene was carried out by the E. coli strain BW3110 with the expression plasmid pJOE5940.1 in the rhamnose promotor system. E. coli was further cultivated on LB medium consisting of bacto peptone $\left(10 \mathrm{~g} \cdot \mathrm{L}^{-1}\right)$, yeast extract $\left(5 \mathrm{~g} \cdot \mathrm{L}^{-1}\right)$ and $\mathrm{NaCl}\left(10 \mathrm{~g} \cdot \mathrm{L}^{-1}\right)$ at a $\mathrm{pH}$ value of 7.0 . For cell disruption cells were centrifuged, washed with aqueous $\mathrm{NaCl}$ solution $(0.9 \%)$, suspended in aqueous $\mathrm{Na}_{2} \mathrm{HPO}_{4}$ $(100 \mathrm{mM})$ at a $\mathrm{pH}$ value of 7 , treated by ultrasound and again centrifuged. The resulting supernatant protein extract was used for further experiments.

Particles of the company Align Chemicals (Amersham, UK) were used for the immobilization of enzymes. Each immobilization was done in a column with a volume of $1 \mathrm{~mL}$. To prepare for immobilization, the empty column weight was first recorded, the particles were then packed into columns, the dry weight of the packed column was determined, the package was rinsed with two column volumes of 2-propanol and weighed again after $10 \mathrm{~min}$. The pore volume can be calculated from the wet weight of the column and the density of the 2-propanol. The column was then rinsed with five times the column volume of phosphate buffer ( $0.5 \mathrm{M}, \mathrm{pH}$ 6.8). For immobilization, $3 \mathrm{~mL}$ of 
centrifuged raw extract was used and flowed through the column using a syringe. The column was than incubated for $12 \mathrm{~h}$ at $4{ }^{\circ} \mathrm{C}$ with the remaining raw extract. After immobilization, an air-filled syringe was used to press the residual raw extract solution out of the column and the protein concentration was measured. The amount of immobilized protein can be calculated from the initial and residual protein concentrations. As reference, unloaded particles treated in the same way as described above were used but without protein loading.

The activity of the immobilized proteins in the respective columns was determined by rinsing the columns with $3 \mathrm{~mL}$ of a $1 \mathrm{~g} \cdot \mathrm{L}^{-1}$ formaldehyde solution, squeezing out the liquid after $30 \mathrm{~min}$ with an air-filled syringe and measuring the formaldehyde concentration. The enzyme activity was derived from the difference of the formaldehyde concentrations between protein loaded and reference column.

Biocatalytic reactions were performed in a pressure reactor (Büchi AG, Uster, Switzerland) at $37^{\circ} \mathrm{C}$ on $500 \mathrm{~mL}$ scale. The formaldehyde and methanol concentrations were determined by quadrupole mass spectroscopy with liquid inlet (Variolytics, Stuttgart, Germany). Calibration of the mass spectrometer was done with methanol/formaldehyde solutions of known concentration.

\subsection{Chemo-/Biocatalytic Oxidation Cascade}

$\mathrm{CH}_{4}, \mathrm{CO}_{2}$ and $\mathrm{O}_{2}$ in a ratio of 9:9:1 was fed into the chemocatalytic reactor and was partly converted to formaldehyde. A $1 \mathrm{~L}$ bioreactor was used to produce methanol and formic acid from the gas obtained downstream the chemocatalytic reactor.

In the first chemocatalytic step the feed was passed through the homemade plug flow quartz reactor described above which was equipped with $25 \mathrm{mg}$ of the silica supported $\mathrm{VO}_{\mathrm{x}}$ catalyst, V/SBA- 15 . A tube furnace was employed to reach the desired reaction temperature of $575^{\circ} \mathrm{C}$. The gas flow was adjusted to $300 \mathrm{~mL} \cdot \mathrm{min}^{-1}$ via a mass flow controller (MKS-Instruments, Andover, MA, USA).

The formaldehyde-containing product gas from chemocatalysis was passed through a $150{ }^{\circ} \mathrm{C}$ heated stainless-steel capillary (inner diameter: $3 \mathrm{~mm}$ ) and fed into the buffer solution to run the biocatalytic conversion. Using a stirrer, the gas bubbles were shredded at a speed of $1500 \mathrm{rpm}$ for better mass transfer from the gas phase into the liquid phase. In the biocatalytic reactor, free FDM or FDM immobilized on particles was introduced and the temperature of the buffer solution was kept at $37{ }^{\circ} \mathrm{C}$ by means of a thermostat. In detail, $500 \mathrm{~mL}$ of the $0.5 \mathrm{M}$ phosphate buffer and $176 \mathrm{mg}$ free FDM in raw extract or $176 \mathrm{mg}$ FDM in raw extract immobilized onto $2 \mathrm{~g}$ IB-150A were placed in the stirrer tank for the biocatalytic disproportionation of formaldehyde at atmospheric pressure. The reaction was stopped when a $\mathrm{pH}$ value of 6.3 was reached. Online monitoring of the formaldehyde and methanol concentration was realized by a quadrupole mass spectrometer with electron ionization and a membrane inlet for liquids enabling the detection of volatile components from the solution (200 amu, Variolytics, Stuttgart, Germany).

\subsection{Product Separation}

The selectivity of polydimethylsiloxane (PDMS) membranes (PolyAn, Berlin, Germany) was determined by the use of the aforementioned mass spectrometer with membrane inlet using a PTFE membrane for reference measurements. The pressure in the membrane module was 0.16 mbar and the temperature of the solution $25^{\circ} \mathrm{C}$. Membranes were allowed to swell in the respective solution for at least $12 \mathrm{~h}$ to become fully functional. The volume of the solution was $500 \mathrm{~mL}$ and the flow at the membrane inlet was $10 \mathrm{~mL} \cdot \mathrm{min}$.

The depletion of methanol over time was investigated with the M12 membrane. The used membrane area was $0.005 \mathrm{~m}^{2}$ and the volume of the solution was $500 \mathrm{~mL}$. To improve mass transfer each solution was stirred. Methanol was collected using a cooling trap and the pressure at the permeate 
side was 20 mbar. Selectivity for methanol was calculated on the base of its concentrations $c$ at the permeate and feed side according to Equation (9):

$$
S=\frac{c_{\text {permeate }}}{c_{\text {feed }}}
$$

For ion exchange experiments Purolite A111 (Purolite, Bala Cynwyd, PA, USA) was used for the separation of formic acid. The material was activated by washing first with $4 \mathrm{wt} \% \mathrm{NaOH}$ for $1 \mathrm{~h}$ and afterwards with double-distilled water. Then, $51.5 \mathrm{~g}$ of Purolite A111 was added to $200 \mathrm{~mL}$ of an $80 \mathrm{mM}$ solution of formic acid. The adsorption was done under stirring at room temperature and the concentration of formic acid was determined by mass spectrometry.

Extraction experiments of formic acid were done using a solution with $0.45 \mathrm{~g} \cdot \mathrm{L}^{-1}$ formic acid. Following this, $15 \mathrm{~mL}$ of formic acid solution and $15 \mathrm{~mL}$ organic phase were mixed. For an optimal segregation the mixtures were centrifuged for $30 \mathrm{~min}$ and were allowed to separate for $2 \mathrm{~h}$ afterwards. The concentration of formic acid in each phase was determined by HPLC-UV.

\section{Results and Discussion}

\subsection{Chemocatalytic Methane Activation-Formaldehyde Production}

Methane from synthetic biogas was transformed in the presence of equimolar amounts of carbon dioxide to formaldehyde. As catalyst $\mathrm{VO}_{\mathrm{x}}$ species supported on SBA-15 (V/SBA-15) were prepared by a grafting procedure since this method provides highly dispersed vanadia species [48] which are selective for formaldehyde. The investigated catalyst possesses a vanadia content of $2.2 \mathrm{wt} \%$ as determined by ICP-OES. In the X-ray diffraction pattern (Figures S1 and S2) reflections for the (100), (110) and (200) planes were observed confirming the hexagonal structure of the pure support and the derived catalyst. Nitrogen sorption experiments (Figures S3 and S4) revealed a specific surface area of $581 \mathrm{~m}^{2} \cdot \mathrm{g}^{-1}$ and a mean pore diameter of $5.1 \mathrm{~nm}$ of the fresh catalyst. Spent V/SBA-15 slightly loses surface area (of $507 \mathrm{~m}^{2} \cdot \mathrm{g}^{-1}$ ) whereas pore diameter is nearly not affected. Raman spectroscopic investigations on the V/SBA-15 catalyst as well as the pure support (Figure S5) revealed that in V/SBA-15 a band at $1035 \mathrm{~cm}^{-1}$ appears, which can be assigned to the $\mathrm{V}=\mathrm{O}$ stretching mode, while the signals from the support at $970 \mathrm{~cm}^{-1}\left(v_{\mathrm{s}}(\mathrm{Si}-\mathrm{OH})\right)$ and $800 \mathrm{~cm}^{-1}\left(v_{\mathrm{s}}(\mathrm{Si}-\mathrm{O}-\mathrm{Si})\right)$ decreased, respectively [31,49-54], indicating the molecular attachment of $\mathrm{VO}_{\mathrm{x}}$ species on the silica surface. Furthermore, the infrared spectrum of the catalyst (Figure S6) shows, beside the typical $v_{\mathrm{s}}(\mathrm{SiO}-\mathrm{H})$ band, a small signal at $3660 \mathrm{~cm}^{-1}$ which has been assigned to the $v_{\mathrm{s}}(\mathrm{VO}-\mathrm{H})$ mode [55]. According to literature the latter species were responsible for a high selectivity towards formaldehyde [50]. The UV-vis DRS spectra (Figure S7) of fresh and spent V/SBA-15 indicate a high amount of monomeric and low oligomeric $\mathrm{VO}_{4}$ species which are stable during reaction. Both the samples possess absorption maxima at $250 \mathrm{~nm}$ and an UV-vis edge energy $\left(E_{\mathrm{g}}\right)$ of $3.5 \mathrm{eV}$. The transparency above $400 \mathrm{~nm}$ is a measure for the absence of polymeric or particulate $\mathrm{VO}_{\mathrm{x}}$ species $[51,52,56]$.

Before integrating into the cascade, the performance of the chemocatalytic first stage was tested under different conditions to evaluate the optimal set of reaction parameters. For this purpose, the reaction temperature and the continuous total flow were varied from $575-650{ }^{\circ} \mathrm{C}$ and from 100-300 $\mathrm{mL} \cdot \mathrm{min}^{-1}$, respectively. The latter correspond to gas hourly space velocities (GHSVs) from $114,000-342,000 \mathrm{~L}_{\mathrm{CH}_{4}} \cdot \mathrm{kg}_{\mathrm{cat}}{ }^{-1} \cdot \mathrm{h}^{-1}$. The resulting selectivity vs. conversion dependency is illustrated in Figure $1 \mathrm{a}$ and shows a typical behavior for this selective oxidation of methane which was normally carried out in the absence of carbon dioxide [6]. 

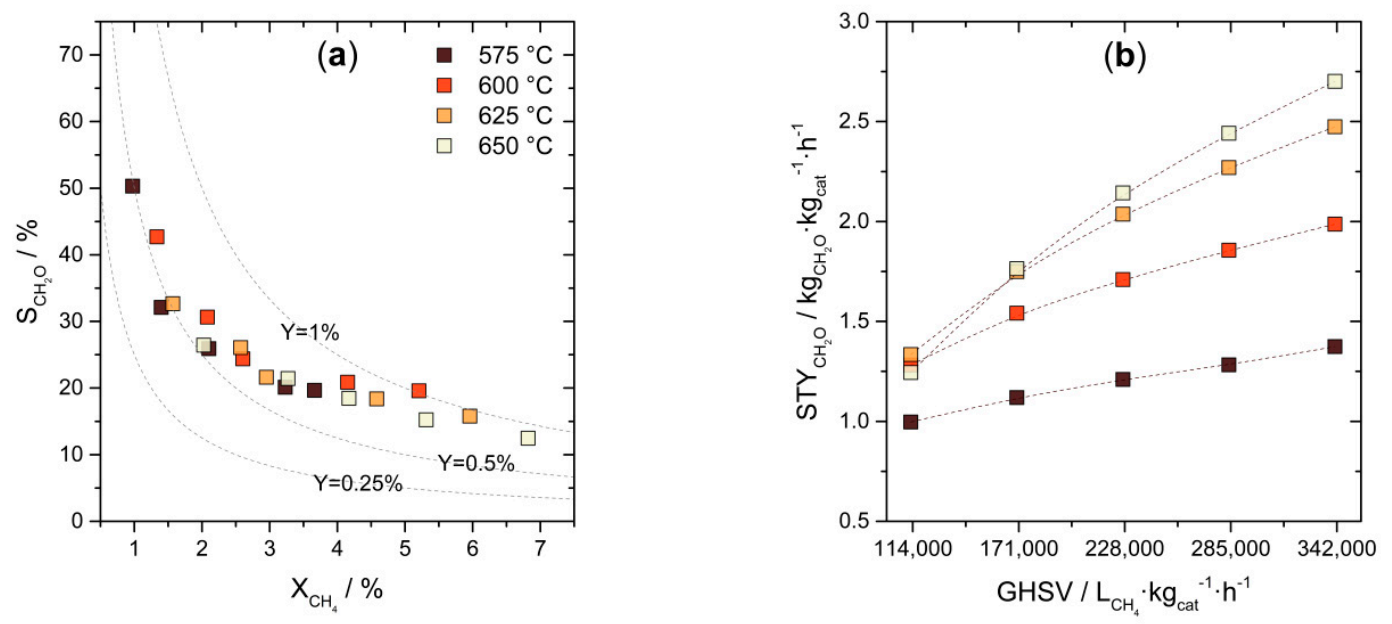

Figure 1. (a) Formaldehyde selectivity $\left(\mathrm{S}_{\mathrm{CH}_{2} \mathrm{O}}\right)$ vs. methane conversion $\left(\mathrm{X}_{\mathrm{CH}_{4}}\right)$ at total flow rates of 100-300 $\mathrm{mL} \cdot \mathrm{min}^{-1}\left(\Delta \mathrm{F}=50 \mathrm{~mL} \cdot \mathrm{min}^{-1}\right)$. The dotted lines represent different possible formaldehyde yields (Y). (b) Space-time yield (STY) of formaldehyde at different flow rates and temperatures.

The observed methane conversion $\left(\mathrm{X}_{\mathrm{CH}_{4}}\right)$ ranges from 1.0 to $6.8 \%$ corresponding to a formaldehyde selectivity $\left(\mathrm{S}_{\mathrm{CH}_{2} \mathrm{O}}\right)$ between 50.3 and $12.5 \%$, respectively. Side products were mainly $\mathrm{CO}$ and $5-10 \%$ $\mathrm{CO}_{2}$. These values are comparable to those reported earlier by our group [31,33] for SBA-15 supported $\mathrm{VO}_{\mathrm{x}}$ catalysts obtained from carbon dioxide free reactant gases. Figure $1 \mathrm{~b}$ depicts the formaldehyde space-time yields (STY) obtained at different conditions. In general, the formaldehyde space-time yield grows continuously with an increasing gas flow. The behavior was observed by increasing the reaction temperature except at very low flow rates caused by overoxidation of produced formaldehyde. The resulting $\mathrm{CH}_{2} \mathrm{O}$ space-time yield ranges from 1.0 to $2.7 \mathrm{~kg}_{\mathrm{CH}_{2} \mathrm{O}} \cdot \mathrm{kg}_{\mathrm{cat}}{ }^{-1} \cdot \mathrm{h}^{-1}$. These values are lower compared to previous studies [32] because of the lower methane concentration in biogas instead of using pure methane/oxygen mixtures.

In order to minimize the content of side products $\left(\mathrm{CO}\right.$ and $\left.\mathrm{CO}_{2}\right)$ the reaction conditions of the highest $\mathrm{CH}_{2} \mathrm{O}$ selectivity were chosen $\left(575^{\circ} \mathrm{C}\right.$, total flow: $\left.300 \mathrm{~mL} \cdot \mathrm{min}^{-1}\right)$ for the experiments which combine chemo- and biocatalysis. Perspectively, the yield of the chemocatalytic conversion unit could be improved by a gas recycling. In this way, a total methane conversion of $89 \%$ with a formaldehyde yield of up to $50 \%$ was already reported by Bafas et al. [57] who separated the formaldehyde from the gas phase via a liquid trap after each cycle.

\subsection{Biocatalytic Disproportionation of Formaldehyde}

The produced formaldehyde can be transformed into methanol and formic acid by FDM. The immobilization of FDM on specific carriers offers long term and continuous processing modes as well as simple product recovery. Hence, we first tested several carriers with different functional groups. The surface specific activity allows a comparison of the different carriers. Table 1 shows the calculated enzyme activity related to the surfaces of the carrier particles. As can be seen, the carriers with a quaternary ammonium compound as functional group showed the highest area-specific activity. With regards to long-term stability, the best results were achieved with the columns IB-150A and IB-C435. After 440 days and 29 measurements the residual activity of the enzyme on a polyacrylic carrier IB-150A with an epoxy group was still 40\%. The carrier IB-C435 with carboxyl groups showed a half-life of 329 days after 348 days and 16 measurements. The carrier IB-150A had a lower half-life of 291 days compared to the carrier IB-C435 but a higher activity. We have chosen carrier IB-150A for further experiments since it offers sufficient initial activity at high long-term stability. 
Table 1. Activity of the FDM on different carriers.

\begin{tabular}{ccccccc}
\hline Column & Bond Type & Matrix & $\begin{array}{c}\text { Functional } \\
\text { Group }\end{array}$ & $\begin{array}{c}\text { Surface Based } \\
\text { Enzyme } \\
\text { Activity } \\
{\left[\mathbf{U} \cdot \mathbf{m m}^{-2}\right]}\end{array}$ & $\begin{array}{c}\text { Number of } \\
\text { Measurements }\end{array}$ & $\begin{array}{c}\text { Measurement } \\
\text { Period/Half-Life/ } \\
\text { Residual Activity } \\
\text { [Days]/[Days]/[\%] }\end{array}$ \\
\hline IB-150A & covalent & polyacrylic & epoxy, nonpolar & 53.3 & 29 & $440 / 291 / 38.8$ \\
\hline IB-150P & covalent & polyacrylic & epoxy, polar & 29.5 & 16 & $145 / 129 / 19.3$ \\
\hline IB-D152 & cationic & polyacrylic & carboxylic group & 32.0 & 14 & $90 / 129 / 37.5$ \\
\hline IB-C435 & cationic & polyacrylic & carboxylic group & 25.7 & 16 & $348 / 329 / 32.0$ \\
\hline IB-A161 & anionic, strong & polystyrene & $\begin{array}{c}\text { quaternary } \\
\text { ammonium }\end{array}$ & 51.8 & 9 & $302 / 96 / 34.0$ \\
\hline IB-A171 & anionic, strong & polystyrene & $\begin{array}{c}\text { quaternary } \\
\text { ammonium }\end{array}$ & 62.5 & 9 & $96 / 28 / 33.5$ \\
\hline IB-A369 & anionic, weak & polystyrene & $\begin{array}{c}\text { quaternary } \\
\text { ammonium }\end{array}$ & 61.5 & 2 & $<20$ \\
\hline IB-EC1 & non-ionic bond & polyacrylic & carboxyl group & 18.6 & 7 & (no activity) \\
\hline IB-S861 & non-ionic bond & polystyrene & aromatic & 26.0 & $<20$ \\
\hline
\end{tabular}

The activity of the immobilized FDM was tested in batch and compared to that obtained over free FDM. The reaction catalyzed by the free FDM was completed seven- to eightfold faster compared to the immobilized FDM what might be caused by mass transport limitations and damages or hindrance of the enzymes caused by the immobilization process. The maximal reaction rate $v_{\max }$ of the free FDM reached a value of $44.7 \mathrm{mmol} \cdot \mathrm{min}^{-1}$ which was much higher than the $v_{\max }$ of the immobilized FDM with $1.6 \mathrm{mmol} \cdot \mathrm{min}^{-1}$. The corresponding Michaelis constants $\mathrm{K}_{\mathrm{m}}$, the substrate concentration with half maximum reaction rate, were determined to a value of $50.9 \mathrm{mM}$ and $41.2 \mathrm{mM}$, respectively.

However, increasing concentrations of methanol and formic acid rapidly inhibit product formation (see $K_{i}$ in Figure 2). In order to illustrate this serious problem, activity tests with the free enzyme at different starting concentrations of either methanol or formic acid, respectively, are shown in Figure 3. In the experiments with formic acid, a buffer was added to exclude inhibition by a lower $\mathrm{pH}$ value. The temporal decrease of the formaldehyde concentration with ongoing reaction time at different product concentrations is obvious. For both products, an inhibition effect was observed. While methanol completely inhibits the reaction at a concentration of $1.5 \mathrm{M}$ an addition of formic acid already stops the reaction at a concentration of $0.7 \mathrm{M}$.

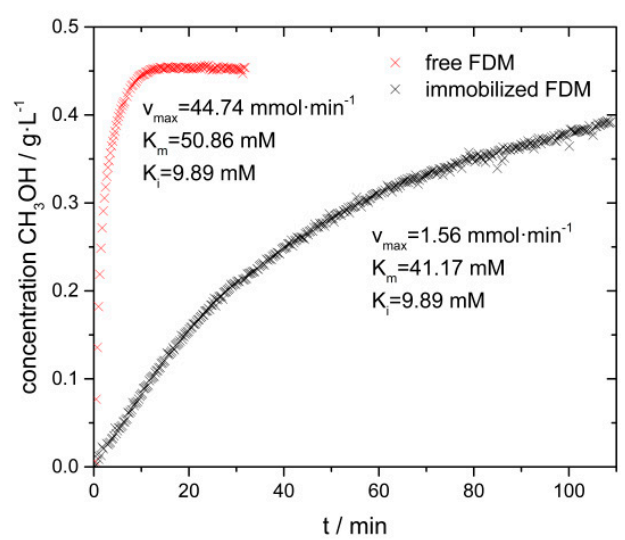

Figure 2. Comparison of the reaction of $176 \mathrm{mg}$ immobilized raw extract on $2 \mathrm{~g}$ carrier particles and the reaction of free enzyme with the same amount of protein on a $500 \mathrm{~mL}$ scale at $37^{\circ} \mathrm{C}$. Also shown are the calculated constants of the Michaelis-Menten kinetics with competitive inhibition $\left(\mathrm{K}_{\mathrm{m}}\right.$-the substrate concentration with half maximum reaction rate, $\mathrm{V}_{\max }$ - maximum reaction rate, $\mathrm{K}_{\mathrm{i}}$ - dissociation constant of the enzyme inhibitor complex). The $\mathrm{CH}_{2} \mathrm{O}$ concentration at the beginning of the reaction was $1 \mathrm{~g} \cdot \mathrm{L}^{-1}$. 

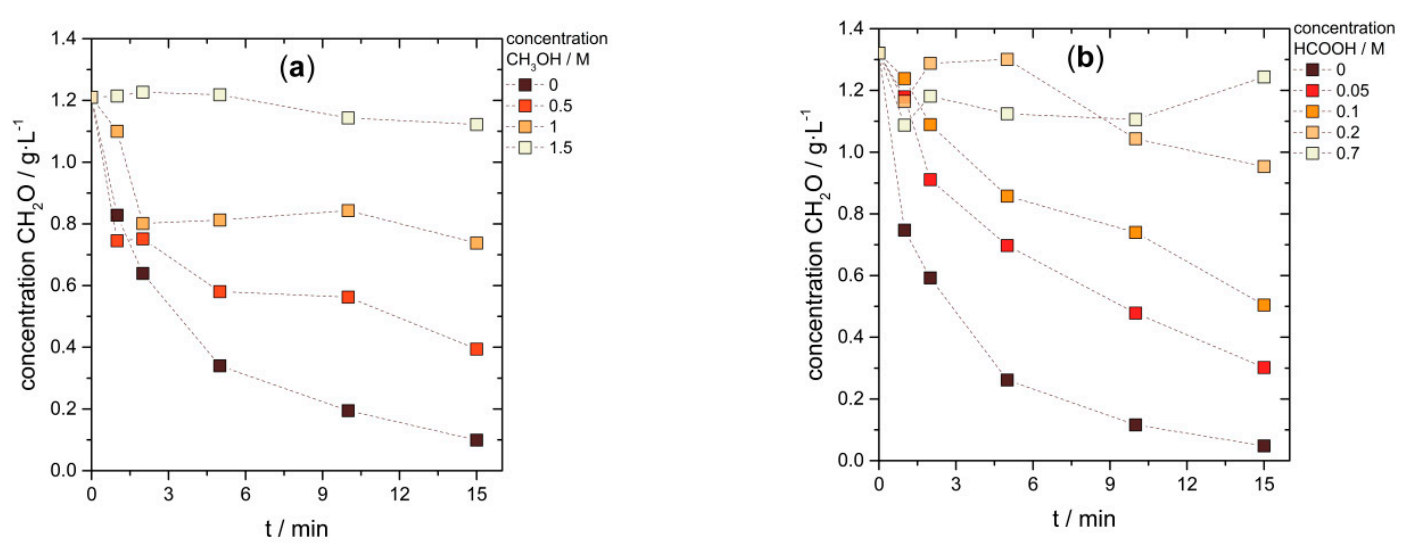

Figure 3. Product inhibition of the free FDM by different concentrations of methanol (a) and formic acid (b).

\subsection{Cascade Combining Chemo- and Biocatalysis}

After the optimization of the separate processes both were combined in the chemo-/biocatalytic oxidation cascade. The used set-up is presented in Scheme 2. The feed was composed of $\mathrm{CH}_{4}, \mathrm{CO}_{2}$ and $\mathrm{O}_{2}$ in the ratio of 9:9:1.

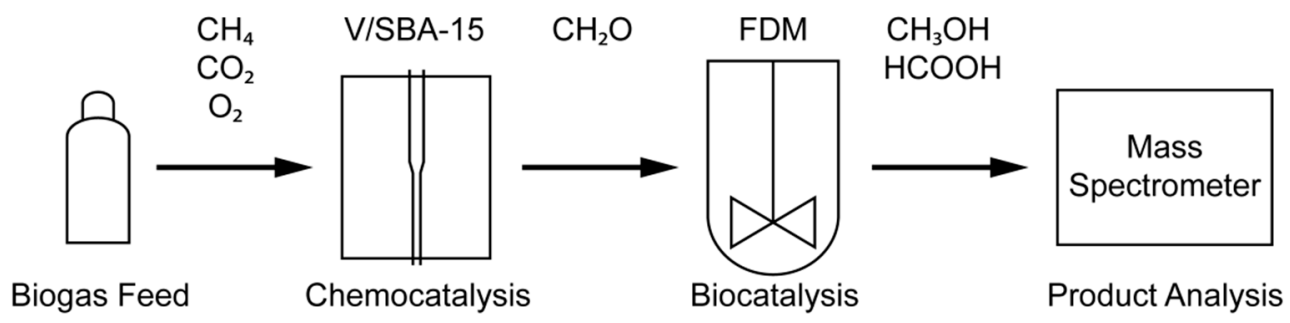

Scheme 2. Set-up for the combination of chemo- and biocatalysis.

In the first mode, formaldehyde was first introduced into the buffer solution by absorption in the absence of free FDM. The formaldehyde feed (chemocatalytic product gas stream) was switched off after $160 \mathrm{~min}$ and $176 \mathrm{mg}$ free FDM containing raw extract dissolved in $10 \mathrm{~mL}$ buffer was added to the stirred vessel. The enrichment of the formaldehyde and the formation of methanol after addition of the FDM are shown in Figure 4a. After $30 \mathrm{~min}$ the reaction was completed. Nearly no formaldehyde could be detected, and the methanol concentration was about $0.2 \mathrm{~g} \cdot \mathrm{L}^{-1}$. The concentration of formic acid increases in the same way and the initial enzyme activity in this experiment was $17,900 \mathrm{nmol} \cdot \mathrm{mg}^{-1} \cdot \mathrm{min}^{-1}$ for both components.

In the second mode, the cascade was operated continuously since the use of immobilized enzymes enables a reaction during absorption. Moreover, product removal is simplified reducing the problems caused by product inhibition, which might be interesting for possible applications. Figure $4 \mathrm{~b}$ shows the enrichment of formaldehyde in the tank as consequence of ongoing feeding from chemocatalytic methane conversion. The constant gassing caused a saturation of the buffer solution with carbon dioxide and methane, so that bubbles entered the membrane inlet of the mass spectrometer and led to the noise of the measurement signal. In parallel, the formaldehyde in the buffer solution within the stirrer tank is simultaneously converted by the immobilized enzyme to methanol and formic acid. After an induction period of about $30 \mathrm{~min}$, the onset of the reaction was observed. The methanol concentration increased linearly up to $20 \mathrm{mg} \cdot \mathrm{L}^{-1}$ and the formaldehyde concentration reached a maximum of $0.3 \mathrm{~g} \cdot \mathrm{L}^{-1}$ at the end of the experiment. The overall productivity was $30 \mathrm{nmol} \cdot \mathrm{mg}^{-1} \cdot \mathrm{min}^{-1}$ for both components. 

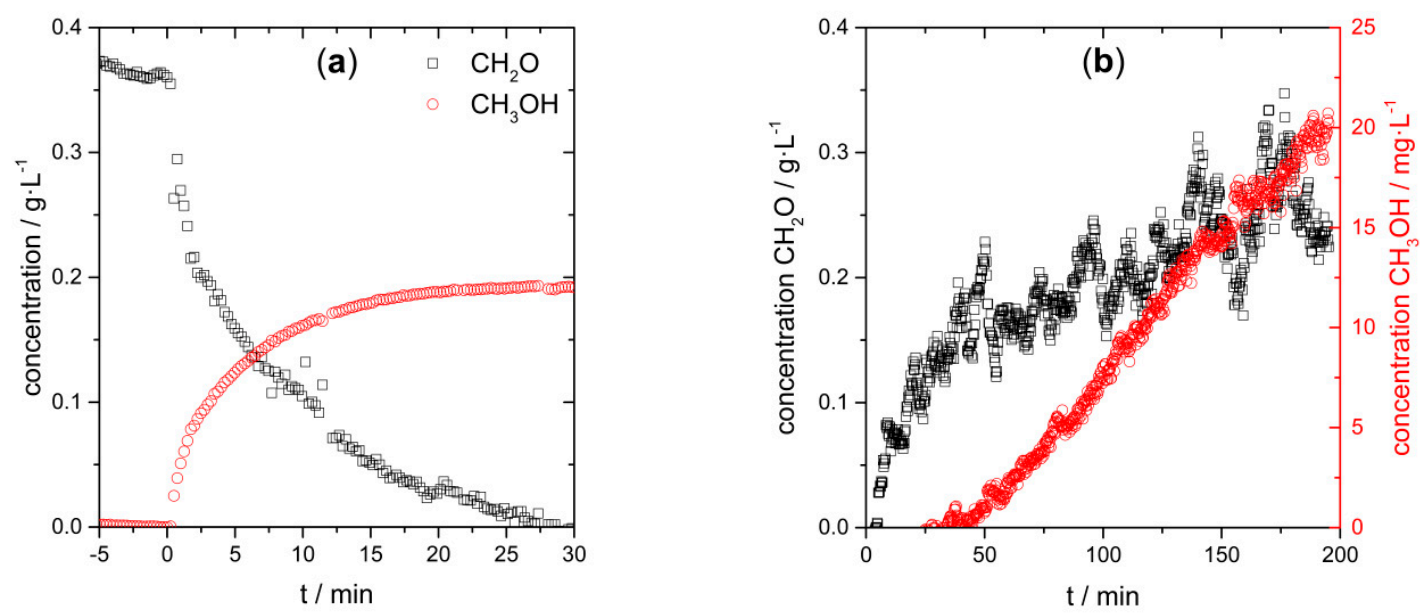

Figure 4. Methane conversion via combination of chemocatalysis $\left(\mathrm{CH}_{4}\right.$ oxidation over V/SBA-15) and biocatalysis $\left(\mathrm{CH}_{2} \mathrm{O}\right.$ disproportionation over FDM). (a) Formation of methanol from formerly produced formaldehyde by freely dissolved FDM. The solution was enriched with formaldehyde until the addition of FDM at $\mathrm{t}=0$. (b) Formation of methanol from formaldehyde by immobilized FDM.

Two points speak clearly against an exact implementation: (i) the lower productivity compared to industrial methanol production and (ii) ongoing product enrichment. Hence, it can be stated that the aforementioned approach only demonstrates the concept and a direct transfer to industry would be impractical. We suggest that productivity could be improved by site-selective immobilization. Moreover, in order to retain the protein structure and high activity of the FDM immobilization in cavities using porous polymers or glasses could be utilized. Furthermore, the inhibition of FDM by formed products could be solved by in situ product removal as it will be shown on idealized mixtures in the following.

\subsection{Product Separation}

As shown in Figure 3, product inhibition is one of the limiting factors for the presented oxidation cascade necessitating an in situ product removal. Accordingly, we investigated first principles on the separation and enrichment of methanol by pervaporation and the separation of formic acid by ion exchange and extraction to evaluate possible routes for further process development.

\subsubsection{Pervaporation of Methanol}

Due to the low methanol concentration in the solution a direct distillation is rather uneconomic. Therefore, pervaporation was investigated since it offers recovery of FDM and enrichment of methanol in one step which can be complemented by further distillation. In this regard we tested different commercially available polydimethylsiloxane membranes. M1 and M2 are different ultrafiltration membranes which are further optimized for either high selectivity (M11, M21) or high flux (M12, M22). The selectivity obtained at different concentrations of methanol is given in Figure 5a. All membranes show a high selectivity at low methanol concentrations. By increasing methanol concentration, selectivity drops. Membrane M12 performed best over the whole concentration range and was therefore chosen for further experiments.

Figure $5 \mathrm{~b}$ illustrates the methanol concentration in the retentate using membrane M12. After $22 \mathrm{~h}$ the methanol concentration decreased from 5 to $2.1 \mathrm{~g} \cdot \mathrm{L}^{-1}$ at $25^{\circ} \mathrm{C}$ and $20 \mathrm{mbar}$ at the permeate side and reached a minimum concentration of $0.1 \mathrm{~g} \cdot \mathrm{L}^{-1}$ at the end of the experiment. 

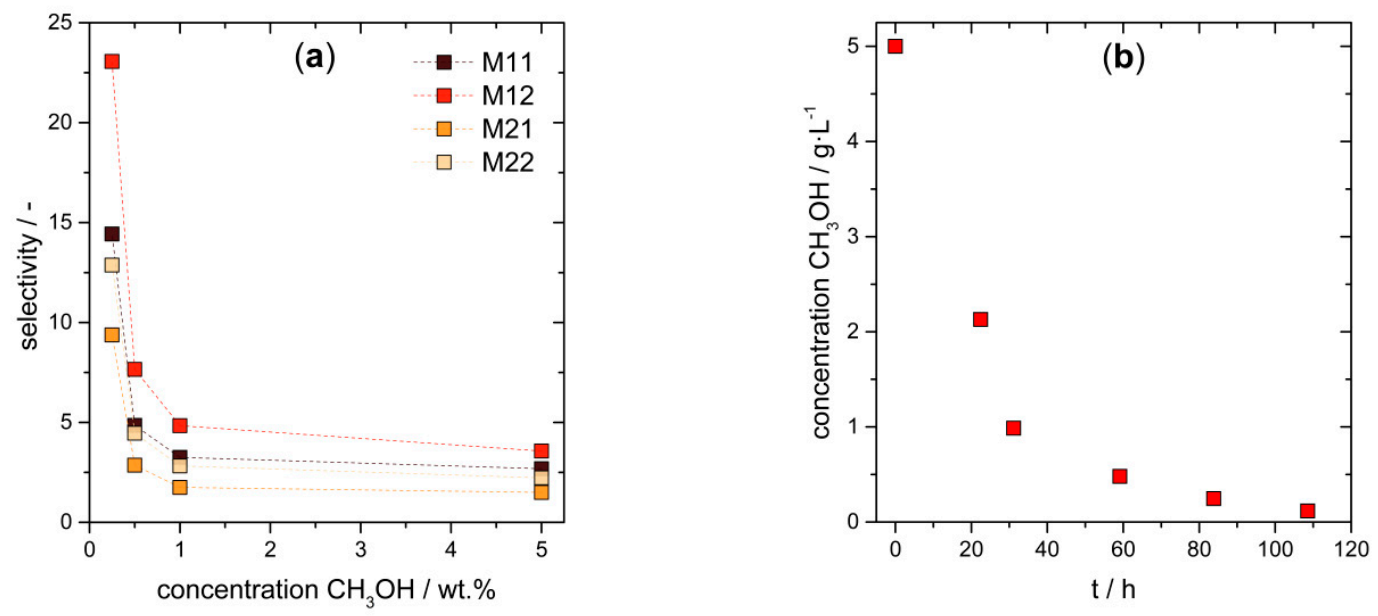

Figure 5. (a) Selectivity of different polydimethylsiloxane (PDMS) membranes at different concentrations of methanol. The pressure in the membrane module used in the mass spectrometer was 0.16 mbar. (b) Depletion of methanol concentration in the retentate using the pervaporation membrane M12. Operating pressure was $20 \mathrm{mbar}$ at the permeate side, $25^{\circ} \mathrm{C}$ in solution and a membrane area of $0.005 \mathrm{~m}^{2}$.

\subsubsection{Ion Exchange and Extraction of Formic Acid}

The separation of formic acid is even more crucial since a decrease of the $\mathrm{pH}$ affects FDM activity (Figure S8). The high boiling point of formic acid and the fact that it is dissociated at the present low concentrations make distillation nearly impractical. Hence, we investigated possibilities of ion exchange (as used in industrial formic acid production) and extraction of formic acid.

When ion exchange is used a buffer solution can no longer be utilized. To maintain a neutral $\mathrm{pH}$ value under these conditions, formate (and carbonate) species have to be directly separated. The formate adsorption was investigated using an ion exchanger (Purolite A111, Figure S9) and an $80 \mathrm{mM}$ solution of formic acid. The loading over time and formic acid concentration are illustrated in Figure 6a.
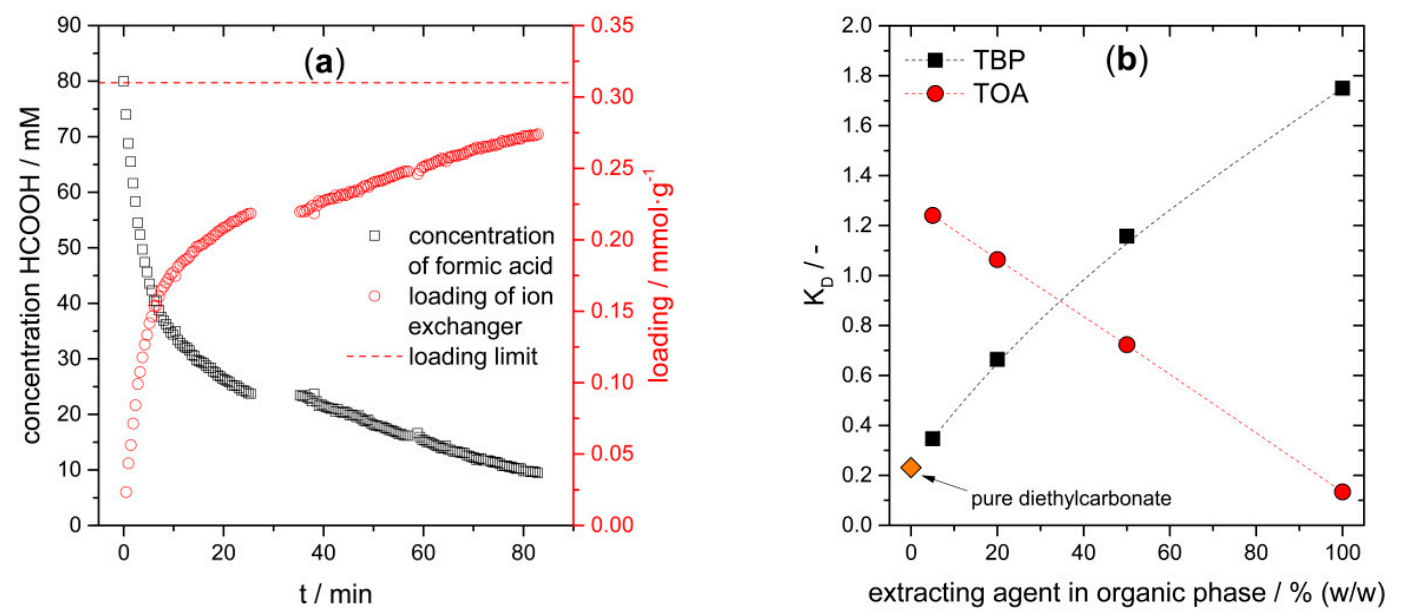

Figure 6. (a) Decrease of formic acid concentration in solution and loading of ion exchanger Purolite A111 over time. In the experiment, Purrolite A111 (51.1 g) was dispersed in $200 \mathrm{~mL}$ of $80 \mathrm{mM}$ formic acid solution. (b) Partition coefficient for formic acid in different mixtures of diethylcarbonate (organic phase) and extracting agents tributylphosphate (TBP) and trioctylamine (TOA). Then, $15 \mathrm{~mL}$ of $0.45 \mathrm{~g} \cdot \mathrm{L}^{-1}$ formic acid solution was extracted with $15 \mathrm{~mL}$ of the respective mixture.

After $8 \mathrm{~min}$ half of the maximum loading $\left(0.31 \mathrm{mmol} \cdot \mathrm{g}^{-1}\right.$ as given by the manufacturer $)$ was reached followed by a decrease in the further loading rate. For regeneration of the ion exchanger a 
basic treatment is required. However, FDM is not stable under basic conditions. In order to overcome this problem commercially available mixed bed filters can be used which allow a separation of different support materials.

Besides ion exchange liquid/liquid extraction represents another option for the separation of formic acid which is also used in industry. For this purpose, different mixtures of tributylphosphate (TBP) or trioctylamine (TOA) in diethylcarbonate were investigated. The partition coefficients $K_{D}$ were determined by extraction of $10 \mathrm{mM}$ formic acid solutions. Prior to these experiments a possible inhibition of FDM by these extraction agents was tested revealing no effect on enzymatic activity. The $K_{D}$ values for the different extraction mixtures are shown in Figure $6 b$. The $K_{D}$ values increase with increasing concentration TBP from $0.23(0 \%$ TBP) to $1.75(100 \%$ TBP) whereas TOA mixtures perform best at low concentration ( $\mathrm{K}_{\mathrm{D}} 1.24$ at $\left.5 \%\right)$. Higher concentrations of TOA decrease the extraction efficiency up to 0.13 for $100 \%$ TOA.

\section{Conclusions}

We presented a successful cascadic combination of (i) chemocatalytic direct methane conversion to formaldehyde and (ii) its biocatalytic disproportionation to methanol and formic acid. Moreover, we illustrate possible pathways for the separation of the two final products.

The cascade is characterized by the following facets:

(1) Productivity. It was possible to produce methanol with an initial FDM activity up to 17,900 $\mathrm{nmol} \cdot \mathrm{mg}^{-1} \cdot \mathrm{min}^{-1}$, which is significantly higher compared to those obtained over MMO, which use methane as substrate.

(2) Production stages. Nowadays, formic acid is prepared in four production stages (methane $\rightarrow$ syngas $\rightarrow$ methanol $\rightarrow$ methyl formate $\rightarrow$ formic acid) whereas the herein presented route requires two steps, only. Moreover, methanol is being produced conventionally in a two-step process including the high endothermic syngas production. In this regard our method is clearly favored due to the exothermic nature of the chemocatalytic oxidation process.

(3) Biomass utilization. It was demonstrated that the production of methanol and formic acid is possible using biogas as methane source. It could be one option for present and future fermentation plants to broaden their product portfolio beyond the generation of electrical energy and biomethane.

With this approach, a novel synthesis route towards both methanol and formic acid starting from methane is now available.

Supplementary Materials: The following are available online at http:/www.mdpi.com/2076-3417/9/14/2798/s1, Figure S1: X-ray diffraction patterns of V/SBA-15 and SBA-15, Figure S2: Small angle X-ray diffraction patterns of V/SBA-15 and SBA-15, Figure S3: BET isotherms of SBA-15, V/SBA-15 and spent V/SBA-15, Figure S4: Pore size distributions of SBA-15, V/SBA-15 and spent V/SBA-15, Figure S5: Raman spectra of V/SBA-15 and SBA-15 under ambient conditions, Figure S6: IR spectra of V/SBA-15 and SBA-15 at room temperature after drying at $600^{\circ} \mathrm{C}$ for $2 \mathrm{~h}$, Figure S7: UV-vis DRS spectra of V/SBA-15 after $2 \mathrm{~h}$ at $600^{\circ} \mathrm{C}$ in air and after application in the chemocatalytic part of the cascade process, Figure S8: Specific FDM acitivity at different $\mathrm{pH}$ values, Figure S9: Loading rate at different loadings of ion exchanger Purolite A111.

Author Contributions: Conceptualization, M.S. and S.W.; methodology, D.S. and M.S.; validation, B.K. and M.S.; investigation, B.K., D.S., T.P. and M.S.; writing—original draft preparation, B.K.; writing-review and editing, S.W., T.P., M.S., D.S.; visualization, B.K.; supervision, M.S. and S.W.; project administration, M.S. and S.W.; funding acquisition, M.S. and S.W.

Funding: This research was funded by Bundesministerium für Bildung und Forschung (BMBF), grant number 031A168A and 031A168C, by Deutsche Forschungsgemeinschaft (DFG), grant number WO 1531/4-1 and by Deutsche Bundesstiftung Umwelt (DBU) with a PhD Scholarship.

Acknowledgments: The authors are grateful to the permanent support of Dieter Bryniok, Markus Pietzsch, Franziska Seifert and Lisa Blaschke.

Conflicts of Interest: The authors declare no conflict of interest. 


\section{References}

1. McFarland, E. Unconventional Chemistry for Unconventional Natural Gas. Science 2012, 338, 340-342. [CrossRef] [PubMed]

2. Van den Oosterkamp, P.F. Synthesis Gas Generation: Industrial. In Encyclopedia of Catalysis; John Wiley \& Sons, Inc.: Hoboken, NJ, USA, 2002. [CrossRef]

3. Rostrup-Nielsen, J.R. Steam Reforming. In Handbook of Heterogeneous Catalysis; Wiley-VCH Verlag GmbH \& Co. KGaA: Weinheim, Germany, 2008. [CrossRef]

4. Gail, E.; Gos, S.; Kulzer, R.; Lorösch, J.; Rubo, A.; Sauer, M.; Kellens, R.; Reddy, J.; Steier, N.; Hasenpusch, W. Cyano Compounds, Inorganic. In Ullmann's Encyclopedia of Industrial Chemistry; Wiley-VCH Verlag GmbH \& Co. KGaA: Weinheim, Germany, 2000. [CrossRef]

5. Weissermel, K.; Arpe, H.-J. Industrial Organic Chemistry; Wiley-VCH Verlag GmbH: Weinheim, Germany, 2008. [CrossRef]

6. Kondratenko, E.V.; Peppel, T.; Seeburg, D.; Kondratenko, V.A.; Kalevaru, N.; Martin, A.; Wohlrab, S. Methane conversion into different hydrocarbons or oxygenates: Current status and future perspectives in catalyst development and reactor operation. Catal. Sci. Technol. 2017, 7, 366-381. [CrossRef]

7. Periana, R.A.; Taube, D.J.; Gamble, S.; Taube, H.; Satoh, T.; Fujii, H. Platinum Catalysts for the High-Yield Oxidation of Methane to a Methanol Derivative. Science 1998, 280, 560-564. [CrossRef] [PubMed]

8. Zimmermann, T.; Soorholtz, M.; Bilke, M.; Schüth, F. Selective Methane Oxidation Catalyzed by Platinum Salts in Oleum at Turnover Frequencies of Large-Scale Industrial Processes. J. Am. Chem. Soc. 2016, 138, 12395-12400. [CrossRef] [PubMed]

9. Lin, M.; Hogan, T.E.; Sen, A. Catalytic Carbon-Carbon and Carbon-Hydrogen Bond Cleavage in Lower Alkanes. Low-Temperature Hydroxylations and Hydroxycarbonylations with Dioxygen as the Oxidant. J. Am. Chem. Soc. 1996, 118, 4574-4580. [CrossRef]

10. Shul'pin, G.B.; Suss-Fink, G.; Shul'pina, L.S. Oxygenation of alkanes with hydrogen peroxide catalysed by osmium complexes. Chem. Commun. 2000, 13, 1131-1132. [CrossRef]

11. Yuan, Q.; Deng, W.; Zhang, Q.; Wang, Y. Osmium-Catalyzed Selective Oxidations of Methane and Ethane with Hydrogen Peroxide in Aqueous Medium. Adv. Synth. Catal. 2007, 349, 1199-1209. [CrossRef]

12. Campbell, A.N.; Stahl, S.S. Overcoming the "Oxidant Problem": Strategies to Use O2 as the Oxidant in Organometallic C-H Oxidation Reactions Catalyzed by Pd (and Cu). Acc. Chem. Res. 2012, 45, 851-863. [CrossRef] [PubMed]

13. Munz, D.; Strassner, T. Propane Activation by Palladium Complexes with Chelating Bis(NHC) Ligands and Aerobic Cooxidation. Angew. Chem. Int. Ed. 2014, 53, 2485-2488. [CrossRef]

14. Palkovits, R.; Antonietti, M.; Kuhn, P.; Thomas, A.; Schüth, F. Solid Catalysts for the Selective Low-Temperature Oxidation of Methane to Methanol. Angew. Chem. Int. Ed. 2009, 48, 6909-6912. [CrossRef]

15. Ab Rahim, M.H.; Forde, M.M.; Jenkins, R.L.; Hammond, C.; He, Q.; Dimitratos, N.; Lopez-Sanchez, J.A.; Carley, A.F.; Taylor, S.H.; Willock, D.J.; et al. Oxidation of Methane to Methanol with Hydrogen Peroxide Using Supported Gold-Palladium Alloy Nanoparticles. Angew. Chem. Int. Ed. 2013, 52, 1280-1284. [CrossRef] [PubMed]

16. Agarwal, N.; Freakley, S.J.; McVicker, R.U.; Althahban, S.M.; Dimitratos, N.; He, Q.; Morgan, D.J.; Jenkins, R.L.; Willock, D.J.; Taylor, S.H.; et al. Aqueous Au-Pd colloids catalyze selective $\mathrm{CH}_{4}$ oxidation to $\mathrm{CH}_{3} \mathrm{OH}$ with $\mathrm{O}_{2}$ under mild conditions. Science 2017, 358, 223-227. [CrossRef] [PubMed]

17. Grundner, S.; Markovits, M.A.C.; Li, G.; Tromp, M.; Pidko, E.A.; Hensen, E.J.M.; Jentys, A.; Sanchez-Sanchez, M.; Lercher, J.A. Single-site trinuclear copper oxygen clusters in mordenite for selective conversion of methane to methanol. Nat. Commun. 2015, 6, 7546. [CrossRef]

18. Tomkins, P.; Mansouri, A.; Bozbag, S.E.; Krumeich, F.; Park, M.B.; Alayon, E.M.C.; Ranocchiari, M.; van Bokhoven, J.A. Isothermal Cyclic Conversion of Methane into Methanol over Copper-Exchanged Zeolite at Low Temperature. Angew. Chem. Int. Ed. 2016, 55, 5467-5471. [CrossRef] [PubMed]

19. Sushkevich, V.L.; Palagin, D.; Ranocchiari, M.; van Bokhoven, J.A. Selective anaerobic oxidation of methane enables direct synthesis of methanol. Science 2017, 356, 523-527. [CrossRef] [PubMed]

20. Park, D.; Lee, J. Biological conversion of methane to methanol. Korean J. Chem. Eng. 2013, 30, 977-987. [CrossRef] 
21. Banerjee, R.; Proshlyakov, Y.; Lipscomb, J.D.; Proshlyakov, D.A. Structure of the key species in the enzymatic oxidation of methane to methanol. Nature 2015, 518, 431-434. [CrossRef] [PubMed]

22. Sirajuddin, S.; Rosenzweig, A.C. Enzymatic Oxidation of Methane. Biochemistry 2015, 54, $2283-2294$. [CrossRef]

23. Ge, X.; Yang, L.; Sheets, J.P.; Yu, Z.; Li, Y. Biological conversion of methane to liquid fuels: Status and opportunities. Biotechnol. Adv. 2014, 32, 1460-1475. [CrossRef]

24. Balasubramanian, R.; Smith, S.M.; Rawat, S.; Yatsunyk, L.A.; Stemmler, T.L.; Rosenzweig, A.C. Oxidation of methane by a biological dicopper centre. Nature 2010, 465, 115-119. [CrossRef]

25. Chen, P.P.Y.; Nagababu, P.; Yu, S.S.F.; Chan, S.I. Development of the Tricopper Cluster as a Catalyst for the Efficient Conversion of Methane into MeOH. Chem CatChem 2014, 6, 429-437. [CrossRef]

26. Chan, S.I.; Lu, Y.-J.; Nagababu, P.; Maji, S.; Hung, M.-C.; Lee, M.M.; Hsu, I.J.; Minh, P.D.; Lai, J.C.H.; Ng, K.Y.; et al. Efficient Oxidation of Methane to Methanol by Dioxygen Mediated by Tricopper Clusters. Angew. Chem. Int. Ed. 2013, 52, 3731-3735. [CrossRef] [PubMed]

27. Liu, C.-C.; Mou, C.-Y.; Yu, S.S.F.; Chan, S.I. Heterogeneous formulation of the tricopper complex for efficient catalytic conversion of methane into methanol at ambient temperature and pressure. Energy Environ. Sci. 2016, 9, 1361-1374. [CrossRef]

28. Fu, G.; Xu, X.; Lu, X.; Wan, H. Mechanisms of Methane Activation and Transformation on Molybdenum Oxide Based Catalysts. J. Am. Chem. Soc. 2005, 127, 3989-3996. [CrossRef] [PubMed]

29. Pirovano, C.; Schönborn, E.; Wohlrab, S.; Narayana Kalevaru, V.; Martin, A. On the performance of porous silica supported VOx catalysts in the partial oxidation of methane. Catal. Today 2012, 192, 20-27. [CrossRef]

30. Wallis, P.; Schonborn, E.; Kalevaru, V.N.; Martin, A.; Wohlrab, S. Enhanced formaldehyde selectivity in catalytic methane oxidation by vanadia on Ti-doped SBA-15. RSC Adv. 2015, 5, 69509-69513. [CrossRef]

31. Wallis, P.; Wohlrab, S.; Kalevaru, V.N.; Frank, M.; Martin, A. Impact of support pore structure and morphology on catalyst performance of VOx/SBA-15 for selective methane oxidation. Catal. Today 2016, 278, 120-126. [CrossRef]

32. Dang, T.T.H.; Seeburg, D.; Radnik, J.; Kreyenschulte, C.; Atia, H.; Vu, T.T.H.; Wohlrab, S. Influence of $\mathrm{V}$-sources on the catalytic performance of VMCM-41 in the selective oxidation of methane to formaldehyde. Catal. Commun. 2018, 103, 56-59. [CrossRef]

33. Seeburg, D.; Bentrup, U.; Kunkel, B.; Ha Vu, T.T.; Dang, T.T.H.; Wohlrab, S. Influence of hydrothermal ageing time on the performance of in situ prepared VMCM-41 catalysts in the selective oxidation of methane to formaldehyde. Microporous Mesoporous Mater. 2019, 109581. [CrossRef]

34. Ohkubo, K.; Hirose, K. Light-Driven C-H Oxygenation of Methane into Methanol and Formic Acid by Molecular Oxygen Using a Perfluorinated Solvent. Angew. Chem. Int. Ed. 2018, 57, 2126-2129. [CrossRef]

35. Morooka, S.; Matubayasi, N.; Nakahara, M. Kinetic Study on Disproportionations of C1 Aldehydes in Supercritical Water: Methanol from Formaldehyde and Formic Acid. J. Phys. Chem. A 2007, 111, 2697-2705. [CrossRef] [PubMed]

36. Akgül, G.; Kruse, A. Hydrothermal disproportionation of formaldehyde at subcritical conditions. J. Supercrit. Fluids 2013, 73, 43-50. [CrossRef]

37. Kato, N.; Shirakawa, K.; Kobayashi, H.; Sakazawa, C. The Dismutation of Aldehydes by a Bacterial Enzyme. Agric. Biol. Chem. 1983, 47, 39-46. [CrossRef]

38. Blaschke, L.; Wagner, W.; Werkmeister, C.; Wild, M.; Gihring, A.; Rupp, S.; Zibek, S. Development of a simplified purification method for a novel formaldehyde dismutase variant from Pseudomonas putida J3. J. Biotechnol. 2017, 241, 69-75. [CrossRef] [PubMed]

39. Rodewyk, B. Formaldehyd-Dismutase aus Pseudomonas Putida J3-Charakterisierung und Anwendungspotential in der Biotechnologie; Fraunhofer IRB Verlag: Stuttgart, Germany, 1998.

40. Hasegawa, T.; Yamano, A.; Miura, K.; Katsube, Y.; Yanase, H.; Kato, N. The X-ray crystal structure of formaldehyde dismutase at $2.3 \AA$ resolution. Acta Crystallogr. Sect. A Found. Crystallogr. 2002, 58, c102. [CrossRef]

41. World Bioenergy Association (WBA). WBA Global Bioenergy Statistics 2018; WBA: Stockholm, Sweden, 2018.

42. Vita, A.; Italiano, C.; Previtali, D.; Fabiano, C.; Palella, A.; Freni, F.; Bozzano, G.; Pino, L.; Manenti, F. Methanol synthesis from biogas: A thermodynamic analysis. Renew. Energy 2018, 118, 673-684. [CrossRef] 
43. Arena, F.; Mezzatesta, G.; Zafarana, G.; Trunfio, G.; Frusteri, F.; Spadaro, L. How oxide carriers control the catalytic functionality of the $\mathrm{Cu}-\mathrm{ZnO}$ system in the hydrogenation of $\mathrm{CO}_{2}$ to methanol. Catal. Today 2013, 210, 39-46. [CrossRef]

44. Arena, F.; Mezzatesta, G.; Zafarana, G.; Trunfio, G.; Frusteri, F.; Spadaro, L. Effects of oxide carriers on surface functionality and process performance of the $\mathrm{Cu}-\mathrm{ZnO}$ system in the synthesis of methanol via $\mathrm{CO}_{2}$ hydrogenation. J. Catal. 2013, 300, 141-151. [CrossRef]

45. Spadaro, L.; Santoro, M.; Palella, A.; Arena, F. Hydrogen Utilization in Green Fuel Synthesis via $\mathrm{CO}_{2}$ Conversion to Methanol over New Cu-Based Catalysts. ChemEngineering 2017, 1, 19. [CrossRef]

46. Arena, F.; Mezzatesta, G.; Spadaro, L.; Trunfio, G. Latest Advances in the Catalytic Hydrogenation of Carbon Dioxide to Methanol/Dimethylether. In Transformation and Utilization of Carbon Dioxide; Bhanage, B.M., Arai, M., Eds.; Springer: Berlin/Heidelberg, Germany, 2014; pp. 103-130. [CrossRef]

47. Iglesias, J.; Melero, J.A.; Bautista, L.F.; Morales, G.; Sánchez-Vázquez, R.; Andreola, M.T.; Lizarraga-Fernández, A. Zr-SBA-15 as an efficient acid catalyst for FAME production from crude palm oil. Catal. Today 2011, 167, 46-55. [CrossRef]

48. Baltes, M.; Cassiers, K.; Van Der Voort, P.; Weckhuysen, B.M.; Schoonheydt, R.A.; Vansant, E.F. MCM-48-Supported Vanadium Oxide Catalysts, Prepared by the Molecular Designed Dispersion of VO(acac)2: A Detailed Study of the Highly Reactive MCM-48 Surface and the Structure and Activity of the Deposited VOx. J. Catal. 2001, 197, 160-171. [CrossRef]

49. Wang, C.-B.; Herman, R.G.; Shi, C.; Sun, Q.; Roberts, J.E. $\mathrm{V}_{2} \mathrm{O}_{5}-\mathrm{SiO}_{2}$ xerogels for methane oxidation to oxygenates: Preparation, characterization, and catalytic properties. Appl. Catal. A 2003, 247, 321-333. [CrossRef]

50. Launay, H.; Loridant, S.; Nguyen, D.; Volodin, A.; Dubois, J.; Millet, J. Vanadium species in new catalysts for the selective oxidation of methane to formaldehyde: Activation of the catalytic sites. Catal. Today 2007, 128, 176-182. [CrossRef]

51. Gao, X.; Bare, S.R.; Weckhuysen, B.M.; Wachs, I.E. In Situ Spectroscopic Investigation of Molecular Structures of Highly Dispersed Vanadium Oxide on Silica under Various Conditions. J. Phys. Chem. B 1998, 102, 10842-10852. [CrossRef]

52. Schraml-Marth, M.; Wokaun, A.; Pohl, M.; Krauss, H.-L. Comparison of grafted vanadia species on $\mathrm{ZrO}_{2}$, $\mathrm{TiO}_{2}, \mathrm{SiO}_{2}$ and $\mathrm{TiO}_{2} / \mathrm{SiO}_{2}$ mixed oxides. J. Chem. Soc. Faraday Trans. 1991, 87, 2635-2646. [CrossRef]

53. Morey, M.; Davidson, A.; Eckert, H.; Stucky, G. Pseudotetrahedral $\mathrm{O}_{3 / 2}$ VO Centers Immobilized on the Walls of a Mesoporous, Cubic MCM-48 Support: Preparation, Characterization, and Reactivity toward Water As Investigated by 51V NMR and UV-Vis Spectroscopies. Chem. Mater. 1996, 8, 486-492. [CrossRef]

54. Strunk, J.; Bañares, M.A.; Wachs, I.E. Vibrational Spectroscopy of Oxide Overlayers. Top. Catal. 2017, 60, 1577-1617. [CrossRef]

55. Voort, P.V.D.; White, M.G.; Mitchell, M.B.; Verberckmoes, A.A.; Vansant, E.F. The effect of water on the structure of supported vanadium oxide structures. An FT-RAMAN, in situ DRIFT and in situ UV-VIS diffuse reflectance study. Spectrochim. Acta Part A 1997, 53, 2181-2187. [CrossRef]

56. Bulánek, R.; Čapek, L.; Setnička, M.; Čičmanec, P. DR UV-vis Study of the Supported Vanadium Oxide Catalysts. J. Phys. Chem. C 2011, 115, 12430-12438. [CrossRef]

57. Bafas, I.C.; Constantinou, I.E.; Vayenas, C.G. Partial oxidation of methane to formaldehyde with $50 \%$ yield in a continuous recycle reactor separator (CRRS). Chem. Eng. J. 2001, 82, 109-115. [CrossRef]

(C) 2019 by the authors. Licensee MDPI, Basel, Switzerland. This article is an open access article distributed under the terms and conditions of the Creative Commons Attribution (CC BY) license (http://creativecommons.org/licenses/by/4.0/). 